ISSN 2077-1827. Гуманізація навчально-виховного процесу. 2019, №. 6 (98)

РОЗДІЛ. ВИЩА ШКОЛА

\title{
ВИЩА ШКОЛА
}

УДК 378.937 + 378.126

\section{ПАНАСЕНКО Елліна}

докт. пед. наук, професор, завідувач кафедри практичної психології, ДВНЗ «Донбаський державний педагогічний університет»

пров. Учительський, 1, м. Слов'янськ, Донецька обл., Україна, 84112

E-mail: ellinapanasenko@ukr.net

\section{МАКАРЕНКО Андрій}

канд. пед. наук, доцент, доцент кафедри медико-біологічних основ охорони життя та цивільного захисту, ДВНЗ «Донбаський державний педагогічний університет»

пров. Учительський, 1, м. Слов'янськ, Донецька обл., Україна, 84112

E-mail: makarenko.slavyansk@gmail.com

\section{РЕЙЛЯН Юлія}

студентка факультету фізичного виховання, ДВНЗ «Донбаський державний педагогічний університет»

пров. Учительський, 1, м. Слов'янськ, Донецька обл., Україна, 84112

E-mail: reylyan.yliya@gmail.com

ТЕОРЕТИЧНІ Й ПРИКЛАДНІ АСПЕКТИ ФОРМУВАННЯ ГЕНДЕРНОЇ КОМПЕТЕНТНОСТІ СТУДЕНТІВ ВИЩИХ ПЕДАГОГІЧНИХ ЗАКЛАДІВ ОСВІТИ

Анотація. У статті розкрито сутність основних дефініцій дослідження («стать», «гендер», «гендерна компетентність особистості», «гендерна компетентність студента закладу вищої педагогічної освіти») у наукових працях зарубіжних i вітчизняних учених. Гендерну компетентність трактовано як інтегроване особистісне утворення, що передбачає наявність ціннісного ставлення до розвитку особистості з позицій гендерного підходу, грунтовних наукових знань про сутність, специфіку гендеру та особливості його прояву в суспільстві, та виявляється в активній діяльності під час розв'язання різноманітних особистісних, соціальних і професійних завдань. Визначено ознаки гендерної компетентності фахівців педагогічних спеціальностей: багатофункціональність (застосування у вирішенні проблемних ситуацій побутової, особистісної, соціальної та професійної областей); міждисциплінарність (вивчення циклу психолого-педагогічних та гуманітарних дисциплін); багатомірність (інтеграція інтелектуальних здібностей, особистісні якості, а також комунікативні навички та вміння).

Представлено два етапи формування гендерної компетентності у студентів - майбутніх педагогів: науково-теоретичний (засвоєння гендерних знань 3 урахуванням профілю майбутньої професії) та практично-діяльнісний

(C) Панасенко Е., Макаренко А., Рейлян Ю. 2019 
(набуття досвіду демократичних відносин у житті студентів за рахунок їх участі у семінарах-тренінгах, практичних заняттях, науково-дослідних проектах, конференціях, круглих столах з гендерної тематики).

Визначено педагогічні умови формування гендерної компетентності у студентів закладів вищої педагогічної освіти (організація взаємодії між учасниками освітнього процесу на принципах партнерства, толерантності та відкритості; адекватність правил i моделей гендерної поведінки демократичній культурі правового громадянського суспільства; збагачення студентів знаннями щодо специфіки статевих особливостей, розуміння різних технологій і моделей життя жінок і чоловіків).

Виокремлено складові структури гендерної компетенції студентів вищих педагогічних закладів освіти: ціннісно-смисловий, когнітивнозмістовий та рефлексивно-діяльнісний компоненти. Схарактеризовано зміст кожного компоненту.

Ключові слова: стать, гендер, гендерна компетентність, педагогічні умови формування гендерної компетентності, структура гендерної компетентності, заклад вищої освіти, підготовка фахівців.

Постановка проблеми в загальному вигляді та їі зв'язок 3 важливим науковими чи практичними завданнями. Проблема формування гендерної компетентності у студентів вищих педагогічних закладів освіти набуває особливого звучання в контексті державної гендерної політики в Україні, що викликано новими трансформаційними процесами як у світовій спільноті, так і в нашій державі. Серед найбільш актуальних завдань, які потребують негайного вирішення, варто виокремити такі: формування у студентів схильності до відмовлення від традиційних статеворольових стереотипів і застарілих орієнтацій на самореалізацію у професійній діяльності; набуття студентами здатності до корекції власних гендерних настанов. Особливої уваги, на нашу думку, нині потребує розроблення i змістовне наповнення компетентностей педагогів, адже саме вони мають навчати і виховувати майбутніх членів суспільства, здійснювати психологопедагогічну допомогу в мінливих політичних, економічних та соціальних умовах. Отже, обгрунтування сутності, визначення структурних компонентів гендерної компетентності, їх максимальна конкретизація є основною умовою ефективності їі формування у майбутніх фахівців сфери освіти.

Аналіз останніх досліджень і публікацій, в яких започатковано розв'язання даної проблеми i на які спирається автор, виділення невирішених раніше частин загальної проблеми, котрим присвячується означена стаття. Різні аспекти проблеми гендеру, гендерної ідентичності дослідили зарубіжні вчені, зокрема С. Бем, Ж. Дувін, А. Іглі, Б. Ллойд, Г. Олпорт, Дж. Спенс та ін.

Питання теорії та методології гендеру висвітлено у працях І. Горошко, I. Жеребкіної, Г.Тьомкіної та ін. Проблеми реалізації принципів гендерної рівності в освітній процес вищої школи представлено у роботах Т. Булавіної, Л.Бут, Т. Говорун та ін.). Сучасні дослідження в сфері гендерної психології та педагогіки здійснюють О. Кікінежді, І. Кльоціна, 
В. Кравець та ін.). Шляхи інтеграції гендерного підходу у систему вищої освіти презентовано у наукових студіях М. Букач, І. Іванової, І. Луценко, О. Цокур та ін. Теоретична й практична готовність фахівців до гендерного виховання й освіти дітей та молоді стала предметом досліджень Л. Булатової, О. Петренко, О. Сухомлинської, Л. Штильової та ін.).

Формулювання цілей статті. Мета статті полягає у вивченні сутності та особливостей формування гендерної компетентності студентів вищих педагогічних закладів освіти.

Виклад основного матеріалу дослідження з повним обгрунтуванням отриманих наукових результатів. Зарубіжники ученими здійснено вагомий внесок у розроблення гендерної теорії і методології гендерних досліджень, а також успішної інтеграції ідей гендерного підходу в освітній процес закладів вищої освіти. Для визначення поняття «стать» вони застосовують терміни «sex» та «gender». Термін «sex» у зарубіжних джерелах потрактовано як стать у біологічному й соціальному контексті, де фіксується призначення індивіду від народження, що засноване на типі геніталій. Поняття «gender» розкрито як процес навчання, прийняття ролі, оволодіння поведінковими діями, що вже засвоєні індивідом як відповідні певному гендерному статусу [8].

Учений Л. Ніколсон підкреслює необхідність використання поняття «гендер» як самостійного і відмінного від категорії «стать», що має сильні біологічні підвалини, адже стало очевидним, що відмінності між чоловічим i жіночим мають саме соціальне, а не природне джерело [9].

Вітчизняний дослідник А. Фесенко стверджує, що на відміну від західних досліджень, розроблення теорії гендера в Україні акцентує увагу не на проблемах жінок, а на гендерних відносинах жінок i чоловіків у суспільстві, оскільки праці вітчизняних авторів грунтуються на доведенні не лише біологічних відмінностей між чоловіками i жінками, а й їхнього розподілу на певні соціальні ролі, форми діяльності, різницю в поведінці, ментальних та емоційних характеристиках [2].

Крім того, А. Фесенко зазначає, що поняття гендера виявилося надзвичайно цікавим не лише для певних науково-теоретичних доробок українських дослідників, але й для тих політичних теорій і партій, які виходили з необхідності зміни соціального статусу жінки в суспільстві. Тому одним із розповсюджених визначень поняття «гендер» $є$ розуміння його як соціальної конструкції, в межах якої розглядається конструювання гендера через різноманітні інститути соціалізації, культуру, розподіл праці. В межах цього підходу гендер розглядається як організована модель соціальних відносин між жінками і чоловіками, яка не лише характеризує їхні стосунки в родині, але й визначає їхні соціальні відносини в основних інститутах суспільства [2].

Варто зазначити, що визначення змісту поняття «гендер» українськими дослідниками коливається від досить розсунутих меж багатокомпонентної структури, яка включає характеристики біологічної статі, гендерних стереотипів, гендерних норм, гендерної ідентичності, гендерних стеореотипів; до охоплення суто соціальних особливостей статі людини, іiі 
соціально визначеної приналежності до певної статі, соціально-рольового статусу особистості, що визначає можливості в усіх сферах життєдіяльності; проблем самопочуття, самореалізації чоловіка і жінки в певному суспільстві; системи міжстатевих стосунків, яка визначається соціально-політичними та економічними умовами; особливостей діяльності з організації ситуативної поведінки у світлі нормативних уявлень про аттитьюди та дії, що відповідають категорії приналежності за статтю [7].

В сучасній науковій літературі виділено три групи гендерних стереотипів. До першої групи дослідники відносять стереотипи маскулінності - фемінінності. Стереотип фемінінності визначає жінку як істоту залежну, емоційну, красиву, турботливу, ласкаву, ніжну, що $є$ пасивнорепродуктивним початком. Другу групу складають уявлення про розподіл професійних i сімейних ролей між чоловіками і жінками. Для останніх значущою вважається роль матері, домогосподині, але аж ніяк не кар'єра, професійний успіх. Третя група гендерних стереотипів визначає зміст статевовідповідної праці. Типово жіноча діяльність повинна мати обслуговуючий, виконавський характер, та не передбачати інструментальності, творчості, лідерства [6].

Нині підготовка фахівців у закладах вищої педагогічної освіти має відбуватися 3 урахуванням гендерного компоненту. Її прикінцевим результатом повинен бути достатній рівень сформованості у здобувачів вищої освіти гендерної компетентності. По-перше, перед кожним студентом у системі вищої освіти ставиться мета всебічного й професійного розвитку їі особистості, соціальної компетентності й відповідальності, що вимагає формування в них якостей у співвідношенні 3 їх соціостатевою роллю та очікуваннями суспільства щодо поведінки жінок і чоловіків, а по-друге, чим менше обмежуються можливості життя студентів у плані обох статей у процесі освіти, тим більше вони виявляються підготовленими до майбутньої професійної діяльності. На цій підставі, визначаючи гендерну компетентність студентів не тільки їхньою підготовкою до життя в демократичному суспільстві, а саме як процес відбудови демократичних відносин у житті самих студентів, варто наголосити, що змістом вищої освіти, адекватним формуванню гендерної компетентності, $\epsilon$ засвоєння студентами гендерних відносин, статеворольових цінностей в суспільній сфері життя, потреб, інтересів, форм діяльності, зумовлених демократичним ладом i дією демократичних інституцій $[1 ; 3 ; 4]$.

Гендерну компетентність ми трактуємо як інтегроване особистісне утворення, що передбачає наявність ціннісного ставлення до розвитку особистості 3 позицій гендерного підходу, грунтовних наукових знань про сутність, специфіку гендеру та особливості його прояву в суспільстві, та виявляється в активній діяльності під час розв'язання різноманітних особистісних, соціальних і професійних завдань. Гендерну компетентність студентів педагогічного вишу представляємо як внутрішнє потенційного цілісне утворення майбутнього фахівця сфери освіти, що характеризується наявністю цілісного знання про сутність гендеру, специфіку його структури 
та функціонування в суспільстві взагалі та в системі освіти зокрема, власним ціннісним ставленням до розвитку особистості вихованців (учнів) з позиції гендерного підходу, а також умінням застосовувати гендерні знання в професійній педагогічній діяльності та комунікаціях.

Гендерна компетентність належить до групи загальних компетентностей фахівця, адже вона характеризується такими ознаками, якот: багатофункціональність, що передбачає іiі застосування у вирішенні проблемних ситуацій побутової, особистісної, соціальної та професійної областей; міждисциплінарність, що вимагає вивчення цілої низки психологопедагогічних та гуманітарних дисциплін; багатомірність, що передбачає інтеграцію інтелектуальних здібностей, особистісні якості, а також комунікативні навички та вміння [5].

Формування гендерної компетентності у студентів педагогічних вишів передбачає реалізацію двох етапів цього спеціально організованого процесу: 1) науково-теоретичного, що передбачає засвоєння гендерних знань 3 урахуванням профілю майбутньої професії; 2) практично-діяльнісного, що сприяє набуттю досвіду демократичних відносин у житті студентів за рахунок їх участі у семінарах-тренінгах, практичних заняттях, науководослідних проектах, конференціях, круглих столах з гендерної тематики.

Педагогічними умовами ефективної організації процесу формування гендерної компетентності студентів $є$ :

- організація взаємодії між студентами і студентками, студентами i викладачами має відбуватися на принципах партнерства, толерантності та відкритості;

- створювані правила і моделі гендерної поведінки, образ мислення студентів повинен бути адекватним демократичній культурі правового громадянського суспільства, що в майбутньому гарантуватиме успіх в обраній фаховій діяльності;

- збагачення у студентів знань щодо специфіки вияву статевих особливостей жінок і чоловіків у різних сферах їх особистісної й професійної самореалізації, розуміння різних технологій i моделей життя жінок i чоловіків, вміння трансформувати конфлікти з особами своєї та протилежної статі на засадах філософії ненасильства $[3 ; 4 ; 5]$.

В структурі гендерної компетенції студентів вищих педагогічних закладів освіти виділяємо: ціннісно-смисловий, когнітивно-змістовий та рефлексивно-діяльнісний компоненти. Кожен 3 цих компонентів має специфічний зміст і виконує певні функції.

Ціннісно-смисловий компонент гендерної компетенції майбутнього фахівця-педагога $є$ індикатором особистісної значущості компетенції. Так, сформованість гендерної компетенції свідчить про наявність ціннісного ставлення до представників обох статей, в тому числі i до себе як представника конкретного статі; позитивних гендерних установок; про прийняття різних типів гендерної ідентичності, різноманіття проявів гендерної поведінки, ідей гендерної рівності в соціумі; про розуміння і подоланні власних стереотипізованих уявлень про гендерні особливості 
хлопчиків і дівчаток (чоловіків і жінок); про здатність до аналізу життєвих і педагогічних ситуацій 3 позиції гендерного підходу; про ціннісних орієнтаціях, що визначають ставлення до педагогічної діяльності з позиції гендерного підходу; про готовність здійснювати педагогічний супровід процесу гендерної соціалізації особистості.

Когнітивно-змістовий компонент гендерної компетенції майбутнього педагога $\epsilon$ теоретичною основою для формування гендерної компетенції. Тільки спираючись на наявні знання, фахівець може здійснювати свою діяльність професійно. Цей компонент гендерної компетенції передбачає оволодіння студентами сукупністю науково-теоретичних знань: про сутність гендеру, гендерної диференціації та іiі культурної обумовленості; про гендерні моделі, гендерні стереотипи і установки в різних культурах; зміни в гендерній сфері; законодавчі документи 3 питань рівноправності чоловіків і жінок у суспільстві; проблеми працевлаштування та ситуації на ринку праці; про гендерні особливості особистості чоловіків і жінок та особливості гендерної соціалізації хлопчиків і дівчаток; про вплив різних інститутів соціалізації на становлення гендерної ідентичності дитини; методи гендерного виховання.

Рефлексивно-діяльнісний компонент гендерної компетенції майбутнього педагога виражається у сформованості необхідних умінь та навичок для реалізації гендерного підходу у професійній діяльності. До таких навичок і умінь можна віднести вміння помічати гендерні проблеми в розвитку суспільства і реагувати на них; критичного аналізу своєї позиції в гендерних питаннях; усвідомлення та самоаналізу власної поведінки і своїх гендерних особливостей; оцінювання впливу різних чинників на формування гендерних уявлень, ролей, ідентичності; організація професійної діяльності на основі ідей гендерної рівності; прагнення здобувати, аналізувати та систематизувати знання з гендерної проблематики з різних джерел.

Для формування гендерної компетентності студентів педагогічних вишів доцільним $€$ введення гендерної тематики у навчальні гуманітарні дисципліни, а також нових навчальних дисциплін «Гендерна психологія», «Гендерна педагогіка», «Гендерна освіта», «Психологія статі», «Психологія сексуальності», «Психологія сім’ї» та ін., викладання яких доцільно здійснювати шляхом проблемного викладу матеріалу та впровадження активних методів навчання (евристичні бесіди, міні-дискусії, тренінгові вправи, метод наративу тощо). Серед найбільш ефективних засобів формування гендерної культури студентської молоді варто відзначити соціально-педагогічний тренінг, під час проведення якого доцільно використовувати інтерактивну лекційну частину, рольову гру, дискусію, обговорення типових i складних ситуацій в групі, практичні вправи, відеотренінг, твір-роздум, моделювання ситуацій тощо.

Висновки 3 даного дослідження і перспективи подальших розвідок у даному напрямку. Питання гендерної рівності і демократії, гендерної культури та гендерної компетентності нині значно актуалізувались, суттєво впливаючи на розв'язання проблем вітчизняної системи вищої педагогічної 
ISSN 2077-1827. Гуманізація навчально-виховного процесу. 2019, №. 6 (98)

РОЗДІЛ. ВИЩА ШКОЛА

освіти. У професійно-педагогічному просторі відбулося осмислення об’єктивної потреби в імплементації нової й необхідної для фахівця педагогічної галузі гендерної компетентності. Задля формування у майбутніх педагогів гендерної компетентності необхідне спеціально організоване навчання й виховання, яке розкривало б особливості теоретичних концепцій та технологій гендерного аналізу, сприяло б ефективному проведенню ними заходів зі статевого виховання й гендерної соціалізації дітей та молоді в закладах освіти. Отже, гендерна компетентність $є$ основою для становлення таких професійно важливих новоутворень особистості педагога, як-от: гендерна культура, гендерна чутливість та гендерна свідомість.

\section{СПИСОК ВИКОРИСТАНОЇ ЛІТЕРАТУРИ}

1. Бондар О., Кухаренко Т., Куц В. Гендерні аспекти економічного розвитку. Відкритий світ. 2002. № 4. С. 10-11.

2. Гендерний аналіз українського суспільства / за ред. Т. Мельник. Київ: ПРООН, 1999. 185 c.

3. Говорун Т., Кікінежді О. Стать та сексуальність: психологічний ракурс: навч. посібник. Тернопіль: Богдан, 1999. 384 с.

4. Говорун Т. В. Соціалізація статі як фактор розвитку Я-концепції: автореф. дис. ... д-ра психол. наук: 19.00.07 / Нац. пед. ун-т імені М.П. Драгоманова. Київ, 2002. 35 с.

5. Голованова Т. П. Цілі, завдання та зміст педагогіки гендера. Проблеми освіти: науково-методичний збірник. Київ, 2002. Вип. 27. С. 88-95.

6. Гусева Ю. Е., Сабунаева М. Л. Гендерные стереотипы: возрастной аспект. Практикум по гендерной психологии. СПб.: Питер, 2003. С. $153-163$.

7. Згуровський М. 3., Сидоренко С. I., Нікітіна I. O. Інформаційна підтримка впровадження гендерної освіти в Україні. Гендер: реалії та перспективи в украӥнському суспільстві: матеріали Всеукраїнської науково-практичної конференції (Київ, 11-13 грудня 2003 р.). Київ: ПЦ “Фоліант”, 2003. С. 178-179.

8. Лорбер Дж., Фаррел С. Принципы гендерного конструирования. Хрестоматия феминистских текстов. Переводы. / под ред. Е. Здравомысловой, А. Темкиной. СПб.: издательство «Дмитрий Буланин», 2000. С. 187-192.

9. Хрестоматия к курсу «Основы гендерных исследований» / отв. ред. О. А. Воронина. Москва: МЦГИ-МВШСЭН, 2000. 396 с.

Стаття надійшла до редакції 20.11.2019. 
ISSN 2077-1827. Гуманізація навчально-виховного процесу. 2019, №. 6 (98)

РОЗДІЛ. ВИЩА ШКОЛА

\section{ПАНАСЕНКО ЭЛлина}

докт. пед. наук, профессор, заведующий кафедрой практической психологии, ГВУЗ «Донбасский государственный педагогический університет

пер. Учительский, 1, г. Славянск, Донецкая обл., Украина, 84112

E-mail: ellinapanasenko@ukr.net

\section{МАКАРЕНКО Андрей}

канд. пед. наук, доцент, доцент кафедры медико-биологических основ охраны жизни и гражданской защиты, ГВУЗ «Донбасский государственный педагогический университет»

пер. Учительский, 1, г. Славянск, Донецкая обл., Украина, 84112

E-mail: makarenko.slavyansk@gmail.com

\section{РЕЙЛЯН Юлія}

студентка факультета физического воспитания, ГВУЗ «Донбасский государственный педагогический университет»

пер. Учительский, 1, г. Славянск, Донецкая обл., Украина, 84112

E-mail: reylyan.yliya@gmail.com

ТЕОРЕТИЧЕСКИЕ И ПРИКЛАДНЫЕ АСПЕКТЫ ФОРМИРОВАНИЯ ГЕНДЕРНОЙ КОМПЕТЕНТНОСТИ СТУДЕНТОВ ВЫСШИХ ПЕДАГОГИЧЕСКИХ УЧРЕЖДЕНИЙ ОБРАЗОВАНИЯ

Резюме. В статье раскрыта сущность основных дефиниций исследования («пол», «гендер», «гендерная компетентность личности», «гендерная компетентность студента учреждения высшего педагогического образования») в научных трудах зарубежных и отечественных ученых. Гендерную компетентность раскрыто как интегрированное личностное образование, которое предполагает наличие ценностного отношения к развитию личности с позиций гендерного подхода, глубоких научных знаний о сущности, специфике гендера и особенностей его проявления в обществе, и проявляется в активной деятельности при решении различных личностных, социальных и профессиональных задач.

Определены признаки гендерной компетентности специалистов педагогических специальностей: многофункциональность (применение в решении проблемных ситуаций бытовой, личной, социальной и профессиональной областей); междисциплинарность (изучение цикла психолого-педагогических и гуманитарных дисциплин); многомерность (интеграция интеллектуальных способностей, личностные качества, а также коммуникативные навыки и умения).

Представлены два этапа формирования гендерной компетентности у студентов - будущих педагогов: научно-теоретический (усвоение гендерных знаний с учетом профиля будущей профессии) и практично-деятельностный (приобретение опыта демократических отношений в жизни студентов за счет их участия в семинарах-тренингах, практических занятиях, научноисследовательских проектах, конференциях, круглых столах по гендерной тематике). 
ISSN 2077-1827. Гуманізація навчально-виховного процесу. 2019, №. 6 (98)

РОЗДІЛ. ВИЩА ШКОЛА

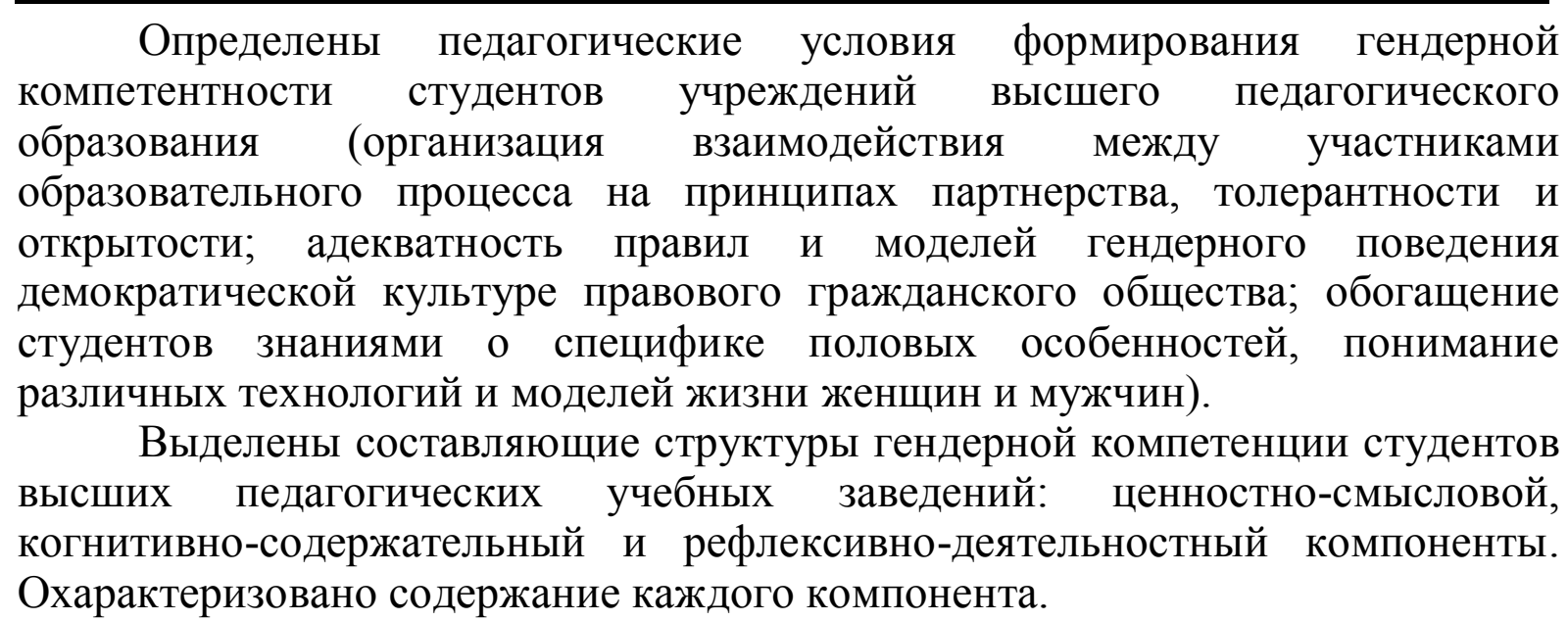

Ключевые слова: пол, гендер, гендерная комптентнисть, педагогические условия формирования гендерной компетентности, структура гендерной компетентности, учреждение высшего образования, подготовка специалистов.

\section{PANASENKO Ellina}

Doctor of Pedagogical Sciences, Professor, Head of the Department of Practical Psychology, Donbas State Teacher's Training University

1, Vchytelskyi Lane, Sloviansk, Donetsk region, Ukraine, 84112

E-mail: ellinapanasenko@ukr.net

\section{MAKARENKO Andrii}

Ph.D (Pedagogy), Associate Professor, Associate Professor at the Department of Medical and Biological Basis of Life Security and Civil Protection, Donbas State Teacher's Training University

1, Vchytelskyi Lane, Sloviansk, Donetsk region, Ukraine, 84112

E-mail: makarenko.slavyansk@gmail.com

\section{REILIAN Yulia} University

Student of Faculty of Physical Education, Donbas State Teacher's Training

1, Vchytelskyi Lane, Sloviansk, Donetsk region, Ukraine, 84112

E-mail: reylyan.yliya@gmail.com

\section{THE THEORETICAL AND APPLIED ASPECTS OF GENDER COMPETENCE FORMATION OF STUDENTS OF HIGHER PEDAGOGICAL INSTITUTIONS}

Summary. The article describes the essence of the basic definitions of the research («sex», «gender», «gender competence of personality», «gender competence of a student of higher education institution») in scientific works of foreign and domestic scientists. Two stages of students (future teachers) gender competence formation are presented: scientific-theoretical and practical-activity. The pedagogical conditions of gender competence formation of students of higher pedagogical institutions are enlightened. The components of structure of gender 
competence of students of higher pedagogical institutions are distinguished: valuesemantic, cognitive-content and reflexive-activity components.

Keywords: sex, gender, gender competence, the pedagogical conditions of gender competence formation, the structure of gender competence, higher educational institution, the specialists training.

Abstract. Introduction. The article describes the essence of the basic definitions of the research («sex», «gender», «gender competence of personality», «gender competence of a student of higher education institution») in scientific works of foreign and domestic scientists. The signs of gender competence of specialists of pedagogical specialties are defined: multifunctionality, interdisciplinarity, multidimensionality. Two stages of students (future teachers) gender competence formation are presented: scientific-theoretical and practicalactivity. The pedagogical conditions of gender competence formation of students of higher pedagogical institutions are enlightened (organization of interaction between the participants of the educational process on the principles of partnership, tolerance and openness; the adequacy of rules and models of gender behavior to the democratic culture of legal civil society; enriching students with knowledge of sex specifics, the understanding of different technologies and life models of women and men). The components of structure of gender competence of students of higher pedagogical institutions are distinguished: value-semantic, cognitive-content and reflexive-activity components. The content of each component is characterized.

The problem of students gender competence formation of higher pedagogical institutions gets a special sound in the context of the Ukrainian state gender policy, which is caused by new transformational processes both in the world community and in our country.

Analysis of publications. The various aspects of the problem of gender, gender identity have been explored by foreign scholars, including S. Bem, J. Duvin, A. Igli, B. Lloyd, G. Alport, J. Spence and others. The issues of gender theory and methodology are covered in the works of I. Goroshko, I. Zherebkina, G. Tymkina and others. The problems of implementation of the principles of gender equality in the educational process of higher school are presented in the works of T. Bulavina, L. Booth, T. Govorun, etc.).

Purpose. The purpose of the article is to study the essence and peculiarities of gender competence formation of students of higher pedagogical institutions.

Results. Currently, the specialists training in higher education institutions should be taken into considering to the the gender component. Its final result should be a sufficiently high level of gender competency of higher education applicants. The gender competence of students of higher pedagogical institutions we presented as an internal potential holistic formation of the future specialist in the field of education, that characterized by having a comprehensive knowledge of the essence of gender, the specifics of its structure and functioning in society in general and in the education system in particular.

The formation of gender competence of students of higher pedagogical institutions involves the implementation of two stages: 1) scientific and theoretical, which involves the acquisition of gender knowledge, considering the profile of the 
future profession; 2) practical-activity, which facilitates to the acquisition of experience of democratic relations in students' lives.

The pedagogical conditions for effective organization of the process of students' gender competence formation are: the organization of interaction between students on the principles of partnership, tolerance and openness; the rules and models of gender behavior, the students' thinking must be adequate to the democratic culture of legal civil society; the enrichment of students' knowledge about the specificity of the sexual peculiarities exposure of women and men in different areas of their personal and professional self-realization, the understanding of different technologies and models women and men life.

In the structure of gender competence of students of higher pedagogical institutions we distinguish: value-semantic, cognitive-meaningful and reflexiveactivity components. Each of these components has a specific content and performs a specific functions.

For the formation of gender competence of students of pedagogical higher institutions it is advisable to introduce a gender topics in the humanitarian educational disciplines, as well as a new educational disciplines «Gender psychology», «Gender pedagogy», «Gender education», «Psychology of sexuality», «Psychology of family» and others.

Conclusion. For the gender competence formation of future educators, the specially organized education and training is needed, which would reveal the peculiarities of theoretical concepts and technologies of gender analysis, which would facilitate to the effective conduct by them the actions of sexual education and gender socialization of children and young people in the educational institutions. Therefore, the gender competence is the basis for the development of such professionally important new formations of the educator personality as: gender culture, gender sensitivity and gender consciousness.

\section{REFERENCES}

1. Bondar, O., Kukharenko, T., Kuts, V. (2002). Henderni aspekty ekonomichnoho rozvytku [The gender aspects of economical growth]. Vidkrytyi svit-Open world, 4, 10-11. [in Ukrainian].

2. Melnyk, T. (1999). Hendernyi analiz ukrainskoho suspilstva [The gender analyses of Ukrainian society]. Kyiv: PROON, 185 p. [in Ukrainian].

3. Hovorun, T., Kikinezhdi, O. (1999). Stat ta seksualnist: psykholohichnyi rakurs : navch. Posibnyk [Sex and sexuality: psychological aspect]. Ternopil: Bogdan, 384 p. [in Ukrainian].

4. Hovorun, T. (2002). Sotsializatsiia stati yak faktor rozvytku Ya-kontseptsii : avtoref. dys.. ... dokt. psykhol. Nauk [Sex socialization as a development factor of I-conception]. Kyiv: National Pedagogical Dragomanov University, 35 p. [in Ukrainian].

5. Holovanova, T. (2002). Tsili, zavdannia ta zmist pedahohiky hendera [Goals, objectives and content of gender's pedagogy]. Kyiv: Nauk.-metod. tsentr vyshchoi osvity, 27, 88-95. [in Ukrainian]. 
6. Guseva Ju., Sabunaeva, M. (2003). Gendernye stereotipy: vozrastnoj aspekt [Gender stereotypes: the age aspect]. Praktikum po gendernoj psihologii The gender psychology practicum, 153-163. [in Russian].

7. Zghurovskyi, M., Sydorenko, S., Nikitina, I. (2003). Informatsiina pidtrymka vprovadzhennia hendernoi osvity $\mathrm{v}$ Ukraini [Information support of the implementation of gender education in Ukraine. Hender: realii ta perspektyvy $v$ ukrainskomu suspilstvi - The gender: Realities and Perspectives in Ukrainian Society, 178-179. [in Ukrainian].

8. Lorber, Dzh., Farrel, S. (2000). Principy gendernogo konstruirovanija [The principles of gender construction]. Saint Petersburg, 187-192. [in Russian].

9. Voronina, O. (2000). Hrestomatija k kursu «Osnovy gendernyh issledovanij» [Reading Book for the course «The Basics of Gender Studies»]. Moscow: MCGI-MVSHSEN, 396 p. [in Russian].

(англійською мовою переклав Я. Слуцький - кандидат педагогічних наук, викладач іноземної мови, завідувач навчально-методичним кабінетом Донбаського державного коледжу технологій та управління)

\section{УДК 378.6.091.2}

\section{САЯПІНА Світлана}

доктор педагогічних наук, доцент, професор кафедри педагогіки вищої школи ДВНЗ «Донбаський державний педагогічний університет»

вул. генерала Батюка, 19, м. Слов'янськ, 84116, Україна

E-mail:svetlana.sayapina65@gmail.com

\section{КРИВОШАПКО Інеса}

здобувач магістерського рівня освіти ДВНЗ «Донбаський державний педагогічний університет»

вул. генерала Батюка, 19, м. Слов'янськ, 84116, Україна

E-mail:inesskalove1996@gmail.com

\section{РЕАЛІЗАЦІ МОДЕЛІ ВИХОВНОЇ СИСТЕМИ В СУЧАСНОМУ ПЕДАГОГІЧНОМУ УНІВЕРСИТЕТІ}

Анотація. У статті підкреслено, що виховний процес $є$ ядром педагогічної діяльності будь-якого освітнього закладу й розглядається як цілісна динамічна система, системоутворювальним чинником якої є мета розвитку особистості, що реалізується в суб'єкт-суб'єктній взаємодії.

Визначено, що ефективність реалізації розробленої моделі виховної системи залежить від кількох умов: реалізація відбувається за частинами, і ці частини повинні постійно співвідноситися з цілісним спільним баченням системи; забезпечення педагогам та вихованцям суб'єктної позиції в цьому процесі; урахування i максимальне використання зовнішніх i внутрішніх чинників. Акцентовано на тому, що виховна система педагогічного університету - соціальна, штучна, динамічна, самокерована, цілеспрямована, діяльнісна, ціннісно зорієнтована, цілісна, відкрита, складна та ймовірнісна.

(C) Саяпіна С.,Кривошапко I., 2019 